\title{
Evaluation of a bovine pregnancy-associated glycoprotein enzyme-linked immunosorbent assay kit for serological diagnosis of pregnancy in sheep
}

\author{
Avaliação de um kit de ensaio imunoenzimático na deteç̧ão de glicoproteínas associadas \\ à prenhez bovina para o diagnóstico sorológico de gestação em ovinos
}

\author{
Monique Tomazele Rovani ${ }^{I}$ Alfredo Skrebsky Cezar ${ }^{I}$ Melânia Lazzari Rigo \\ Bernardo Garziera Gasperin', II Janduí Escarião da Nóbrega Júnior ${ }^{I}$ \\ Fabrício Dias Torres ${ }^{\mathrm{III}}$ Paulo Bayard Dias Gonçalves ${ }^{\mathrm{I}}$ Rogério Ferreira $^{\mathrm{IV}}$
}

\section{ABSTRACT}

Pregnancy diagnosis is an important tool for farm management. Ultrasonography is the main technique used for pregnancy diagnosis in ewes. As an alternative, radioimmunoassay (RIA) allows accurate and early detection of pregnancy-associated glycoproteins (PAGs) in sheep blood. However, radioactive-based techniques, as RIA, have been increasingly inadvisable due to environmental risk. Homology between ovine and bovine PAGs is high, and ELISA kits used for PAGs detection in cattle are safer than RIA. Thus, this study aimed to evaluate the feasibility of PAGs detection for pregnancy diagnosis in sheep serum samples using an ELISA kit produced for cattle. The sensitivity and specificity of the ELISA kit were $93.5 \%$ and $98.9 \%$, respectively, whereas positive and negative predictive values were $99.0 \%$ and $93.1 \%$, respectively, in comparison to ultrasonography diagnostic (control). PAGs reached consistently detectable concentrations in ovine serum around 33 days after mating. Accuracy of the ELISA test was $96.1 \%$ from 33 days of pregnancy until lambing. After parturition, PAGs were still detectable seven days post-lambing. However, from 21 days postparturition, PAGs from the previous pregnancy were no longer detected in serum samples. In conclusion, the bovine ELISA kit can accurately detect pregnancy in sheep 33 days following mating, while PAGs levels from the previous gestation are no longer detected from 21 days post-partum. The evaluated ELISA test is a reliable tool for pregnancy diagnosis in sheep at random stages and as a complementary exam at early gestation.

Key words: pregnancy-associated glycoproteins, ewe, pregnancy blood test, ELISA kit.

\section{RESUMO}

O diagnóstico de gestação é uma ferramenta importante no manejo da propriedade. A ultrassonografia é a principal técnica utilizada no diagnóstico de prenhez em ovelhas. Como alternativa, o radiomunoensaio (RIA) permite acurácia e a detecção precoce de proteinas associadas à prenhez (PAGs) no sangue. No entanto, as técnicas radioativas, como o RIA, têm sido cada vez mais desaconselháveis, devido ao risco ambiental. A homologia entre PAGs de ovinos e bovinos é alta, e os kits de ELISA utilizados para a detecção de PAGs em bovinos são mais seguros do que RIA. Portanto, este estudo teve como objetivo avaliar a viabilidade de detecção de PAGs no soro ovino para diagnóstico de gestação em soro ovino, utilizando um kit de ELISA produzido para bovinos. A sensibilidade e a especificidade do kit de ELISA foram de 93,5\% e $98,9 \%$, respectivamente, enquanto que os valores preditivos positivo e negativo foram de 99,0\% e 93,1\%, respectivamente, em comparação com a ultrassonografia (utilizada como referência). As PAGs atingiram concentrações consistentemente detectáveis no soro ovino em torno de 33 dias após o acasalamento. A acurácia do teste de ELISA foi de 96,1\% a partir de 33 dias de gestação até o parto. As PAGs ainda eram detectáveis sete dias pós-parto. No entanto, a partir de 21 dias após o parto, as PAGs da prenhez anterior já não eram detectadas no soro. Em conclusão, o kit de ELISA bovino pode detectar a prenhez com precisão em ovelhas a partir de 33 dias após o acasalamento, e os niveis de PAGs da gestação anterior não são detectados a partir de 21 dias pós-parto. O teste de ELISA avaliado é uma ferramenta confiável para o diagnóstico de gestação em ovelhas em estágios aleatórios e como exame complementar no início da gestação.

Palavras-chave: glicoproteinas associadas à gestação, ovelha, teste sanguíneo de prenhez, kit de ELISA.

\section{INTRODUCTION}

Pregnancy diagnosis in small ruminants has been ordinarily performed by abdominal or

\footnotetext{
'Laboratório de Biotecnologia e Reprodução Animal (BioRep), Universidade Federal de Santa Maria (UFSM), Santa Maria, RS, Brasil.

"Laboratório de Reprodução Animal (ReproPel), Universidade Federal de Pelotas (UFPel), Capão do Leão, RS, Brasil.

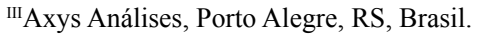

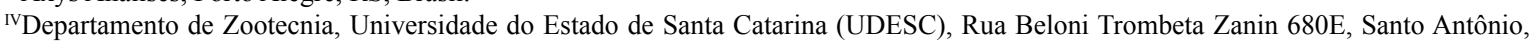
89815-630, Chapecó, SC, Brasil. E-mail: rogério.ferreira@udesc.br. Corresponding author.
} 
rectal ultrasonographic examination, providing high accuracy. However, errors in detecting pregnancy by transrectal or transabdominal ultrasonography can occur, since diagnosis depends on several factors including fetal position, gestational stage and transducer characteristics (KAREN et al., 2004; GANAIE et al., 2009). Therefore, it would be beneficial to examine alternative methods of pregnancy diagnosis in the form of placental proteins detectable by blood analysis (SOUSA et al., 2006; EL AMIRI et al., 2007).

Pregnancy-associated glycoproteins (PAGs) were characterized as major proteins secreted by ruminant trophoblast cells throughout pregnancy. PAGs are structurally and immunologically similar in sheep and cattle (XIE et al., 1991) with several isoforms already identified at the second trimester of pregnancy in cattle (KLISCH et al., 2005). Bovine and ovine cDNA encoding PAG- 1 have $86 \%$ similarity in nucleotide sequences and results in encoded proteins which differ in only 2 amino acids (XIE et al., 1991). There are numerous isoforms of PAGs produced from ovine placenta (e.g., ovPAG-55, 57, 59, 60, 61 and 65), which were identified at random stages of pregnancy and used to develop PAGs-based assays with placental antigens from ewes (XIE et al., 1997; EL AMIRI et al., 2003; EL AMIRI et al., 2004). These studies involving sheep PAGs were based on radioimmunoassay (RIA), a radioactive technique (DE SOUSA et al., 2003; KAREN et al., 2003). However, RIA applicability in laboratorial routine is increasingly constrained, due to the risk of environmental impact.

Commercial enzyme-linked immunosorbent assay (ELISA) kits with high sensitivity and specificity for detection of pregnancy in cattle serum samples are currently available (PIECHOTTA et al., 2011). Recently, an ELISA kit and a near-infrared reflectance spectroscopy (NIRS) test were developed for early diagnosis of pregnancy in small ruminants (ANDUEZA et al., 2014). However, these options are scarce and not commercially available in several countries.

The aim of this study was to test a commercially available ELISA kit (produced for cattle PAGs detection) as a new option for pregnancy diagnosis in early, middle and final gestational stages of sheep, using serum samples. Additionally, PAGs clearance in serum samples post-lambing were determined.

\section{MATERIAL AND METHODS}

\section{Experiment 1}

This experiment was designed to test the suitability of a commercial ELISA kit (IDEXX
Laboratories Inc., Westbrook, Maine, USA) produced for bovine PAGs detection as an alternative to pregnancy diagnosis in sheep, using blood serum samples. Corriedale ewes and Ile de France x Texel crossbred ewes $(n=203)$ at random stages of the estrous cycle or at different stages of pregnancy were used. These animals were grazed on good quality pasture with water ad libitum on four farms in Southern Brazil. All ewes were examined for pregnancy by transabdominal and/or transrectal ultrasonography in a standing and/or sitting position to obtain a definitive diagnosis, using a 6-MHz linear-array transducer (Aquila Vet scanner, Pie Medical, Netherlands). Blood samples were collected from the jugular vein immediately after examination for PAGs detection.

\section{Experiment 2}

The aim of this experiment was to determine at which moment the PAGs reach detectable concentrations in sheep serum after mating. Texel ewes were managed under similar conditions to that described in Experiment 1. Nine non-pregnant ewes, confirmed by ultrasonographic examination, in good body condition ( 3 on a 5-point scale), kept away from rams for the past sixty days, were selected. Estrus was synchronized by insertion of intravaginal sponges containing $62.5 \mathrm{mg}$ medroxyprogesterone acetate (Purifarma, Brazil) for 11 days. At the time of sponge removal, the ewes were treated with eCG (200IU, i.m., Novormon, Intervet, Brazil). One ram of proven fertility was introduced to the flock after sponge withdrawal. Ewes were allowed to mate naturally under field conditions and were checked for mating daily for three days. All ewes were examined for pregnancy twice by transrectal ultrasonography, as mentioned previously, around Day 35 and Day 55 post-mating. Blood samples were collected from pregnant ewes $(\mathrm{n}=5)$ after mating at the following intervals: $18-20,21-22,23-24,26-28,33-35,62-64$, 95-97, and 127-129 days. Serum samples from nonpregnant animals $(n=4)$ collected at interval of 18-20 days after mating were used as negative controls for ELISA tests.

Experiment 3

In order to check PAGs levels from the previous gestation after lambing, six pregnant ewes from the same flock as Experiment 2, which were accompanied until parturition, were chosen. Considering the day of lambing as day zero, blood samples were collected at Days 0, 7, 21, 30 and 45 to determine the pattern of PAGs levels postlambing. Serum samples from non-pregnant ewes 
were used as negative controls for ELISA tests, as described in Experiment 2.

Blood sampling

Blood samples $(4 \mathrm{ml})$ were withdrawn from the jugular vein into vacuum serum tubes and allowed to clot for $30 \mathrm{~min}$ at room temperature before centrifugation at $1.500 \mathrm{~g}$ for $10 \mathrm{~min}$. Serum was placed into cryogenic vials, frozen, and stored at $-20^{\circ} \mathrm{C}$ until assayed for PAGs concentrations.

\section{PAGs immunoassay}

Concentrations of PAGs in sheep serum were detected using a commercialELISA kit developed for catile (IDEXX Bovine Pregnancy Test, IDEXX Laboratories Inc., Westbrook, Maine, USA). ELISA conditions were designed to detect the early presence of PAGs in bovine serum or EDTA treated bovine plasma as a marker for pregnancy in cattle. According to the manufacturer instructions, a microtiter plate format has been configured by coating an anti-PAGs antibody onto the plate. After the incubation of the test sample in the coated well, captured PAGs is detected with a PAGs-specific antibody (detector solution) and horseradish peroxidase conjugate (HRPO conjugate). Unbound conjugate is washed away and $\operatorname{TMB}(3,3$ ', 5,5"'-tetramethylbenzidine) substrate is added to the wells. Color development is proportional to the amount of PAGs in the sample.

The optical density (OD) was quantified by Biotek ELX800 at $650 \mathrm{~nm}$ wave length. In the case that OD values from each sample minus negative control mean $(\mathrm{NCx})$ were equal or greater than 0.300 the ewe was considered pregnant and less than 0.300 not pregnant. In addition, $\mathrm{NCx}$ must be less than or equal to 0.150 and positive control mean (PCx) minus the NCx must be greater than or equal to 0.300 .

\section{Analysis of data}

Ultrasonographic examination was used as standard test to proof ELISA efficiency. For this purpose, data were arranged as follows: correct positive diagnosis (cp), false positive diagnosis (fp), correct negative diagnosis ( $\mathrm{cn}$ ), and false negative diagnosis (fn). From these data, sensitivity $(100 \times \mathrm{cp} / \mathrm{cp}+\mathrm{fn})$, specificity $(100 \times \mathrm{cn} / \mathrm{cn}+\mathrm{fp})$, positive predictive value $(100 \times \mathrm{cp} /$ $\mathrm{cp}+\mathrm{fp})$, negative predictive value $(100 \times \mathrm{cn} / \mathrm{cn}+\mathrm{fn})$ and accuracy $(100 \times \mathrm{cp}+\mathrm{cn} /$ all $)$ were calculated. The PAGs concentrations were expressed as non-transformed means \pm the standard error.

\section{RESULTS}

Experiment 1

ELISA kit was efficient for pregnancy diagnosis at random stages of gestation in sheep. ELISA kit sensitivity was $93.5 \%$, specificity was $98.9 \%$, positive predictive value (PPV) was $99.0 \%$, negative predictive value (NPV) was $93.1 \%$ and accuracy was $96.1 \%$, when compared to ultrasonographic results (Table 1).

\section{Experiment 2}

All of the nine ewes submitted to the hormonal protocol were detected in estrus and were naturally mated in a period of 72 hours after sponge removal. Five ewes were pregnant, as confirmed by ultrasonographic examination at Days 35 and 55 after mating, and kept gestation until lambing. As shown in figure 1A, PAGs reached detectable concentrations in ovine serum around the thirty-third day after mating, since all serum samples from the five ewes confirmed as pregnant by ultrasonographic examination had an $\mathrm{OD}>0.300$ in PAGs-detection ELISA test from Days 33-35 after mating until Days 127-129. Serum samples from non-pregnant ewes ( $\mathrm{n}=4$; negative controls) demonstrated $\mathrm{OD}<0.300$ in PAGs-detection ELISA test (OD -0.00575 \pm 0.002 ).

\section{Experiment 3}

After parturition, PAGs were still detectable $(\mathrm{OD}>0.300)$ at Day 7 post lambing. However, from Day 21 after parturition onwards, PAGs from the previous pregnancy were no longer detected in serum samples (Figure $1 \mathrm{~B}$ and $1 \mathrm{C}$ ). The concentration of PAGs from mating until Day 65 after parturition in the serum from a representative ewe is shown in figure $1 \mathrm{C}$.

\section{DISCUSSION}

Our results showed that the ELISA test developed for bovine PAGs detection can be applied

Table 1 - Contingency table comparing pregnancy diagnosis by PAGs detection in serum samples (ELISA kit) and ultrasonographic examination in ewes.

\begin{tabular}{lccc}
\hline & Pregnant by ultrasonography & Non-pregnant by ultrasonography & Total \\
\hline Pregnant by ELISA & 101 & 1 & 102 \\
Non-pregnant by ELISA & 7 & 94 & 101 \\
Total & 108 & 95 & 203 \\
\hline
\end{tabular}




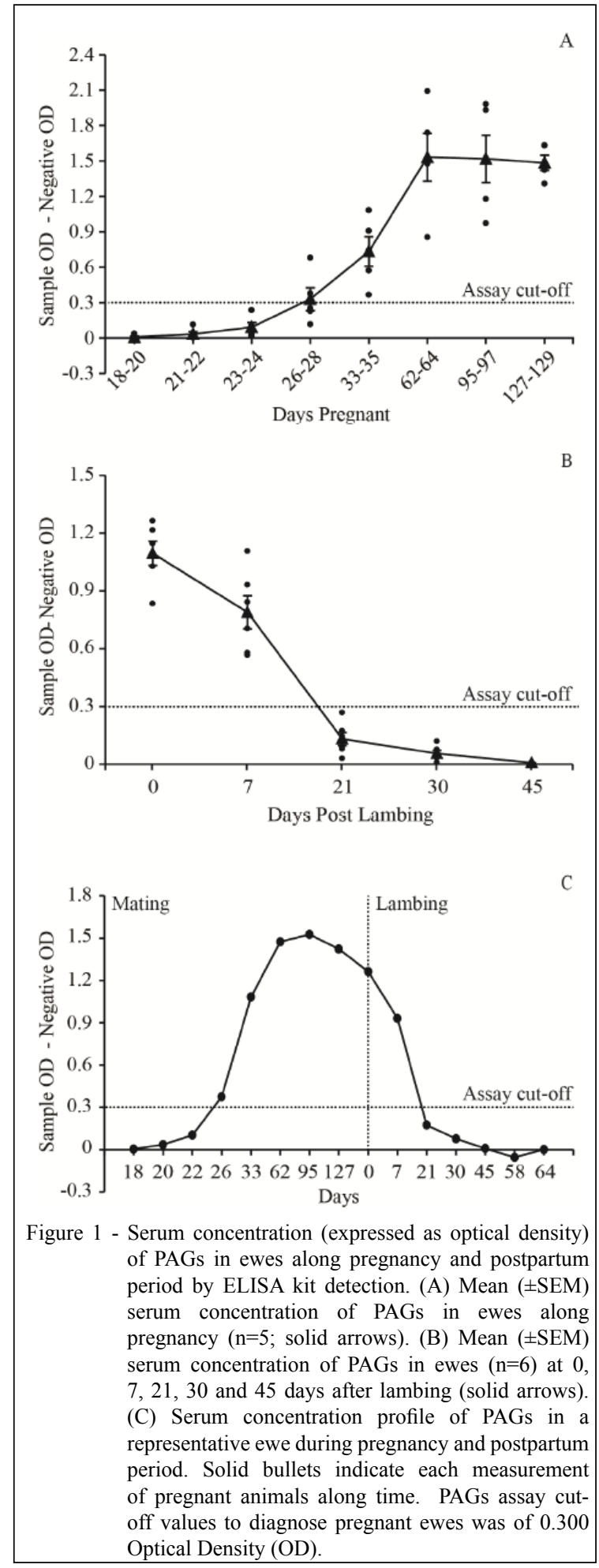

for serological pregnancy diagnosis in sheep, with high sensitivity and accuracy. Although ELISA kits for bovine pregnancy diagnosis by PAGs detection are commercially available (PIECHOTTA et al., 2011), for sheep these kits are scarce and not commercially available in several countries. ELISA test is a valuable alternative to ultrasonography and can also be used as a complementary exam. An advantage of ELISA test relies on the fact that collection, storage and transport of serum samples from the farm to the laboratory do not require any form of advanced technology.

Currently, RIA is the most widespread technique to detect PAGs in serum and milk, both in cattle and sheep (RANILLA et al., 1994; SOUSA et al., 2002; DE SOUSA et al., 2003; KAREN et al., 2003; EL AMIRI et al., 2007). This technique presents high sensitivity and specificity $(100 \%$ and $99.2 \%$, respectively) in diagnosing pregnancy, as demonstrated at Day 29 of pregnancy (KAREN et al., 2003). However, there are restrictions and specific conditions for manipulation of radioactive substances, including structural laboratory requirements. Additionally, radioactive residues are potentially dangerous for people and environment in which it comes in contact. In this context, the ELISA test is safer than RIA and it can be performed in standard laboratories removing the unfavorable and harmful restrictions linked to RIA.

In the present study, sensitivity and specificity of bovine ELISA kit tested for sheep serum samples were $93.5 \%$ and $98.9 \%$, respectively. Sensitivity was slightly lower, while specificity was higher than that expected for bovine serum samples $(99.3 \%$ and $93.8 \%)$, according to the manufacturers information. Accuracy found using sheep serum samples for pregnancy diagnosis by ELISA test were close to those reported by transrectal ultrasonography during a period between 25 to 50 days of gestation around $87 \%$ sensitivity and $96 \%$ specificity (BUCKRELL et al., 1986; GEARHART et al., 1988).

Ultrasonographic accuracy varies with the ultrasound equipment features, gestational period of the ewes and animal's position during examination (KAREN et al., 2004; GANAIE et al., 2009). KAREN et al. (2004) reported the sensitivity of 21.8 to $63.3 \%$ of the transrectal ultrasonography between 18 to 50 days of pregnancy. The same authors demonstrated that fasting prior to scanning and lifting the abdomen during the exam increased the diagnosis sensitivity. These variations are concerns for ultrasonographic diagnosis in the field, and PAGs detection method may help increasing accuracy in some occasions. Nonetheless, transrectal ultrasonography is more often recommended at early stages of gestation (ROMANO $\&$ CHRISTIANS, 2008) while, as pregnancy advances, with the growth of the fetus in the abdominal cavity, a transabdominal exam is more suitable (GANAIE 
et al., 2009). In the present study, transrectal and transabdominal ultrasonography in a standing or sitting position were performed to obtain the final diagnosis.

Based on the findings of the current study, ELISA kit developed for bovine PAGs detection is suitable for accurate pregnancy diagnosis in sheep at 33 days post-mating. In contrast, it was previously demonstrated that RIA for ovine PAGs detection allowed pregnancy diagnosis from 22 days following artificial insemination (KAREN et al., 2003). These discrepant results may be a consequence of different sensitivities and/or different isoforms of PAGs detected by the assays. Furthermore, it is important to highlight that in the present study pregnancy diagnosis was performed 35 and 55 days after mating and that the variation observed in PAGs levels before day 35 may be related to embryo losses. Earlier ultrasonographic examinations would allow evaluate this hypothesis.

The fact that PAGs were no longer detected 21 days after lambing is in accordance with the previously reported postpartum half-life of 4.5 days of these glycoproteins in the ewe (HAUGEJORDEN et al., 2006). Furthermore, the present findings are in agreement with other studies that showed basal levels of PAGs at the fourth week postpartum (RANILLA et al., 1994; RANILLA et al., 1997). As observed in bovine species, PAGs residues from the previous gestation do not present a problem for pregnancy diagnosis in ewes, with respect to the period necessary for postpartum resumption of cyclicity. However, in specific conditions, residual PAGs may confound pregnancy diagnosis after fetal loss and abortion, inducing false-positive diagnosis, although this needs further investigation.

\section{CONCLUSION}

Commercial ELISA kit developed and available for pregnancy diagnosis by bovine PAGs detection also detects ovine PAGs from Day 33 postmating. PAGs levels from the previous gestation are no longer detected from 21 days postpartum. The sensitivity and specificity of the ELISA kit allows its use as an effective and complementary tool for reproductive management in sheep flocks.

\section{ACKNOWLEDGEMENTS}

Authors thank to IDEXX Lab. Inc. for providing ELISA kit and to the farms for providing the animals and animal work facilities. The authors disclosed receipt of the following financial support for the research, authorship, and/or publication of this article: Supported by Conselho Nacional de
Desenvolvimento Científico e Tecnológico (CNPq), Coordenação de Aperfeiçoamento de Pessoal de Nível Superior (CAPES) and Fundação de Amparo á Pesquisa do Estado do Rio Grande do Sul (FAPERGS) from Brazil. MTR was supported by a scholarship from $\mathrm{CNPq}$.

\section{BIOETHICS AND BIOSSECURITY COMMITTEE APPROVAL}

Procedures involving animals were approved by the Ethics in the Use of Animals Committee (CEUA) of the Universidade Federal de Santa Maria.

\section{REFERENCES}

ANDUEZA, D. et al. Early pregnancy diagnosis in sheep using near-infrared spectroscopy on blood plasma. Theriogenology, v.81, n.3, p.509-513, 2014. Available from: <http://www.sciencedirect. com/science/article/pii/S0093691X13004251>. Accessed: Oct. 28, 2010. doi: 10.1016/j.theriogenology.2013.10.016.

BUCKRELL, B.C. et al. The use of real-time ultrasound rectally for early pregnancy diagnosis in sheep. Theriogenology, v.25, n.5, p.665-673, 1986. Available from: <http://www.ncbi.nlm. nih.gov/pubmed/16726157>. Accessed: Oct. 28, 2010. doi: 0093-691X(86)90124-X [pii].

DE SOUSA, N.M. et al. Pregnancy-associated glycoprotein concentrations during pregnancy and the postpartum period in Azawak Zebu cattle. Theriogenology, v.59, n.5-6, p.11311142, 2003. Available from: <http://www.ncbi.nlm.nih gov/pubmed/12527062>. Accessed: Oct. 28, $2010 . \quad$ doi: S0093691X02011603 [pii].

EL AMIRI, B. et al. Measurement of ovine pregnancyassociated glycoprotein (PAG) during early pregnancy in Lacaune sheep. Reproduction in Domestic Animals, v.42, n.3, p.257-262, 2007. Available from: <http://www.ncbi.nlm. nih.gov/pubmed/17506803>. Accessed: Oct. 28, 2010 . doi: 10.1111/j.1439-0531.2006.00761.x.

EL AMIRI, B. et al. Isolation and characterization of eight pregnancy-associated glycoproteins present at high levels in the ovine placenta between day 60 and day 100 of gestation. Reproduction Nutrition Development, v.44, n.3, p.169-181, 2004. Available from: <http://rnd.edpsciences.org/articles/rnd/ ref/2004/04/R4003/R4003.html>. Accessed: Oct. 28, 2010. doi: 10.1051/rnd:2004025.

EL AMIRI, B., et al. Isolation and partial characterization of three pregnancy-associated glycoproteins from the ewe placenta. Molecular Reproduction and Development, v.64, n.2, p.199-206, 2003. Available from: <http://dx.doi.org/10.1002/mrd.10246>. Acesso em: Oct. 28, 2010. doi: 10.1002/mrd.10246.

GANAIE, B.A. et al. Evaluation of different techniques for pregnancy diagnosis in sheep. Small Ruminant Research, v.85, n.2-3, p.135-141, 2009. Available from: <http://www. sciencedirect.com/science/article/pii/S0921448809001618>. Accessed: Oct. 28, 2010. doi: 10.1016/j.smallrumres.2009.09.003.

GEARHART, M.A. et al. Real-time ultrasonography for determining pregnancy status and viable fetal numbers in ewes. Theriogenology, v.30,n.2,p.323-337, 1988. Available from:<http:// 
www.sciencedirect.com/science/article/pii/0093691X8890180X >. Accessed: Oct. 28, 2010. doi: 10.1016/0093-691X(88)90180-X

HAUGEJORDEN, G. et al. Pregnancy associated glycoproteins (PAG) in postpartum cows, ewes, goats and their offspring. Theriogenology, v.66, n.8, p.1976-1984, 2006. Available from: $\quad<$ http://www.sciencedirect.com/science/article/pii/ S0093691X06003128>. Accessed: Oct. 28, 2010. doi: 10.1016/j. theriogenology.2006.05.016.

KAREN,A. et al. Early pregnancy diagnosis in sheep by progesterone and pregnancy-associated glycoprotein tests. Theriogenology, v.59, n.9, p.1941-1948, 2003. Available from: <http://www.ncbi. nlm.nih.gov/pubmed/12600731>. Accessed: Oct. 28, 2010. doi: S0093691X0201289X [pii].

KAREN, A. et al. Accuracy of transrectal ultrasonography for determination of pregnancy in sheep: effect of fasting and handling of the animals. Theriogenology, v.61, n.7-8, p.1291-1298, 2004. Available from: <http://www.sciencedirect.com/science/article/pii/ S0093691X03003376>. Accessed: Oct. 28, 2010. doi: 10.1016/j. theriogenology.2003.07.018

KLISCH, K. et al. Pregnancy associated glycoprotein-1, -6, -7 , and -17 are major products of bovine binucleate trophoblast giant cells at midpregnancy. Molecular Reproduction and Development, v.71, n.4, p.453-460, 2005. Available from: $<$ http://dx.doi.org/10.1002/mrd.20296>. Accessed: Oct. 28, 2010. doi: $10.1002 / \mathrm{mrd} .20296$.

PIECHOTTA, M. et al. Comparison of commercial ELISA blood tests for early pregnancy detection in dairy cows. Journal of Reproduction and Development, v.57, n.1, p.72-75, 2011. Available from: <https://HYPERLINK"http://www.jstage.jst.go.jp/ article/jrd/57/1/57 10-022T/ article>"www.jstage.jst.go.jp/article/ jrd/57/1/57_10-022T/_article $>$. Accessed: Oct. 28, 2010. doi: $10.1262 /$ jrd. $10-022 \mathrm{~T}$.

RANILLA, M.J. et al. Plasmatic profiles of pregnancyassociated glycoprotein and progesterone levels during gestation in Churra and Merino sheep. Theriogenology, v.42, n.3, p.537545, 1994. Available from: <http://www.sciencedirect.com/
science/article/pii/0093691X9490691B >. Accessed: Oct. 28, 2010. doi: 10.1016/0093-691x(94)90691-b.

RANILLA, M.J. et al. Plasma pregnancy-associated glycoprotein and progesterone concentrations in pregnant Assaf ewes carrying single and twin lambs. Small Ruminant Research, v.24, n.2, p.125-131, 1997. Available from: <http://www.sciencedirect. com/science/article/pii/S0921448896009224>. Accessed: Oct. 28, 2010. doi: 10.1016/S0921-4488(96)00922-4.

ROMANO, J.E.; CHRISTIANS, C.J. Early pregnancy diagnosis by transrectal ultrasonography in ewes. Small Ruminant Research, v.77, n.1, p.51-57, 2008. Available from: <http:// www.sciencedirect.com/science/article/pii/S0921448808000308>. Accessed: Oct. 28, 2010. doi: 10.1016/j.smallrumres.2008.02.004.

SOUSA, N.M. et al. Pregnancy-associated glycoproteins (PAG) as pregnancy markers in the ruminants. Journal of Physiology and Pharmacology, v.57, suppl.8, p.153-171, 2006. Available from: $<$ http://www.ncbi.nlm.nih.gov/pubmed/17242480>. Accessed: Oct. 28,2010

SOUSA, N.M. et al. Characterization of pregnancy-associated glycoproteins extracted from zebu (Bos indicus) placentas removed at different gestational periods. Reproduction Nutrition Development, v.42, n.3, p.227-241, 2002. Available from: $<$ http://rnd.edpsciences.org/index.php?option=com_article\&acce ss $=$ standard\&Itemid=129\&url=/articles/rnd/pdf/2002/04/04.pdf $>$. Accessed: Oct. 28, 2010. doi: 10.1051/rnd:2002021.

XIE, S. et al. Multiple pregnancy-associated glycoproteins are secreted by day 100 ovine placental tissue. Biology of Reproduction, v.57, n.6, p.1384-1393, 1997. Available from: $<$ http://www.biolreprod.org/content/57/6/1384.full.pdf + html $>$. Accessed: Oct. 28, 2010. doi: 10.1095/biolreprod57.6.1384.

XIE, S.C. et al. Identification of the major pregnancy-specific antigens of cattle and sheep as inactive members of the aspartic proteinase family. Proceedings of the National Academy of Sciences, v.88, n.22, p.10247-10251, 1991. Available from: $<$ http://www.pnas.org/content/88/22/10247.full.pdf + html $>$. Accessed: Oct. 28, 2010 